\title{
ORT_14 - Expression, purification and characterization of the SARS-CoV-2 nucleocapsid antigen
}

Haroldo Cid da Silva Junior ${ }^{1 *}$; Cristiane Pinheiro Pestana ${ }^{1}$; Fernanda Otaviano Martins ${ }^{1}$; Janaina Figueira Mansur' $^{1}$; Patricia Barbosa Jurgilas ${ }^{1}$; Luãnna Elisa Liebscher Vidal ${ }^{1}$; Ana Paula Corrêa Argondizzo ${ }^{1}$; Mariana Miguez Tardelli Garcia ${ }^{1}$; Renata Chagas Bastos ${ }^{1}$; Gabriela dos Santos Esteves ${ }^{1}$.

${ }^{1}$ Fiocruz/Bio-Manguinhos.

Introduction: SARS-CoV-2 spread rapidly causing a public health crisis worldwide. Currently, emergency vaccines developed against COVID-19 has been used jointly with the adoption of measures to reduce virus transmission are strategies to control the pandemic. However, emergency of new SARS-CoV-2 variants carrying mutations at the spike can become a challenge in vaccine effectiveness and diagnostic detection based only on the spike antigen. The nucleocapsid $(\mathrm{N})$ protein is a $50 \mathrm{kDa}$ protein that plays an important role in replication, transcription and assembly of the viral genome, further to impair the reproductive cycle of the host cell. Also, is the most abundant protein among coronaviruses, highly conserved and particularly immunogenic.

Objective: This study aimed to produce the SARS-CoV-2 $\mathrm{N}$ antigen to be used as a potential target for both vaccine formulations and diagnostic.

Methodology: The nucleotide sequence coding for SARS-CoV-2 $\mathrm{N}$ protein (accession number MN988669.1) was optimized and inserted into N-terminal 6xHis-tag pET28a vector by a custom gene service (GenScript). Lemo21 (DE3) cells were transformed with pET28a+N by electroporation. The culture was grown in selective pressure of antibiotic at $37^{\circ} \mathrm{C}$ until reach optical density $\left(\mathrm{OD}_{600 \mathrm{~nm}}\right)$ of 0.6, when it was induced with $0,4 \mathrm{mM}$ IPTG for 5 hours and $200 \mathrm{rpm}$, and evaluated at $30^{\circ} \mathrm{C}$ and $37^{\circ} \mathrm{C}$. The soluble $\mathrm{N}$ protein was purified using metal ion affinity chromatography (IMAC) and polished at a second purification step performed using Heparin column (Cytiva). The purified fraction was analyzed by SDS-PAGE, western blotting and densitometry to determine identity and purity. Nucleocapsid antigen was analyzed by Size Exclusion Chromatography (SEC) on Superdex 200 column 10/300, gradient SDSPAGE (4-12 \%) and IEF-PAGE (3.0-9.0). Tryptophan fluorescence emission and Circular Dichroism (CD) spectra from $\mathrm{N}$ protein were also obtained. The kinetic thermal denaturation was determined from $25^{\circ} \mathrm{C}$ to $85^{\circ} \mathrm{C}$. $\mathrm{CD}$ analysis were performed in Dichroweb server.

Results: A band about $48 \mathrm{kDa}$, corresponding to molecular weight expected to the SARS-CoV-2 nucleocapsid protein, was observed at both SDS-PAGE 12\% and western blotting using commercial antiSARS-CoV-2 nucleocapsid and anti-histag antibodies. The additional purification step using Heparin after IMAC column gave an improvement of about $10 \%$ in protein purity. SEC analysis demonstrated $\mathrm{N}$ protein with $162 \mathrm{kDa}$ (94\% homogeneity) suggesting a trimer form and by gradient SDS-PAGE (4-12 $\%$ ) presented $52.3 \mathrm{kDa}$ (98\% homogeneity). IEF-PAGE demonstrated isoelectric point higher than 9.0 to the protein. The tryptophan fluorescence and $\mathrm{CD}$ thermogram showed a conformational structure stability until $40^{\circ} \mathrm{C}$. CD spectrum of $\mathrm{N}$ protein was mainly composed of coils.

Conclusion: Our study demonstrated that the SARS-CoV-2 N antigen can be obtained with high level of purity and the protein are being used in different approaches like diagnosis and vaccine development.

Keywords: SARS-CoV-2; nucleocapsid protein; antigen 